\title{
Multiple Hürthle cell adenomas in a patient with thyroid hormone resistance
}

\author{
Gemma Xifra', Silvia Mauri', Jordi Gironès ${ }^{2}$, José Ignacio Rodríguez Hermosa², \\ Josep Oriola ${ }^{3}$, Wifredo Ricart ${ }^{1}$ and José Manuel Fernández-Real ${ }^{1,4,+}$ \\ Departments of ${ }^{1}$ Diabetes, Endocrinology and Nutrition, Hospital Dr Josep Trueta, Girona, Spain \\ ${ }^{2}$ Surgery, Hospital Dr Josep Trueta, Girona, Spain \\ ${ }^{3}$ Biochemistry and Molecular Genetics Department, CDB Hospital Clinic, Barcelona, Spain \\ ${ }^{4}$ CIBERobn, pathophysiology of obesity and nutrition, Spain \\ †J M Fernández-Real is now at Unit of Diabetes, Endocrinology and Nutrition, Hospital de Girona 'Dr Josep Trueta', \\ Carretera de França s/n, 17007 Girona, Spain
}

\author{
Correspondence \\ should be addressed \\ to J M Fernández-Real \\ Email \\ jmfreal@idibgi.org
}

\section{Summary}

Background: Thyroid hormone resistance (RTH) is a rare cause of thyroid dysfunction. High TSH levels, as described in RTH syndrome, are known to be associated with an increased risk of developing thyroid nodules with subsequent growth and malignancy.

Patient findings: In 2006, a 29-year-old Caucasian man presented with a palpable mass in the neck. Increased free thyroxine and triiodothyronine levels were found in the context of unsuppressed TSH levels, despite no signs or symptoms of hyperthyroidism. Ultrasonography revealed a multinodular and enlarged goitre, and fine-needle aspiration cytology revealed suspicious features of malignancy. After excluding pituitary tumour and levothyroxine (L-T $\left.\mathrm{T}_{4}\right)$ treatment, the patient was diagnosed with generalized RTH. Screening for all the known mutations in thyroid hormone receptor- $\beta($ TR $\beta(T H R B)$ ) was negative. Thyroidectomy disclosed five Hürthle adenomas and three hyperplasic nodules. Euthyroidism was achieved after surgery with $6.1 \mu \mathrm{g} / \mathrm{kg}$ per day of $\mathrm{L}-\mathrm{T}_{4}$.

Conclusion: RTH may be a risk factor that predisposes to the development of multiple Hürthle cell adenomas. To our knowledge, this is the first case of multiple Hürthle cell adenomas in a patient with RTH.

\section{Learning points:}

- High TSH levels, as described in RTH syndrome, are known to be associated with an increased risk of developing thyroid nodules, with subsequent growth and malignancy.

- The exact role of $T R \beta$ mutants in thyroid carcinogenesis is still undefined.

- We report the first case of multiple Hürthle cell adenomas associated with RTH.

\section{Background}

Thyroid hormone resistance (RTH) is an inherited syndrome, mostly inherited as an autosomal dominant trait, caused by mutations in the thyroid hormone receptor- $\beta$ $(T R \beta(T H R B))$ gene and characterized by reduced sensitivity to thyroid hormone (TH). The precise incidence is unknown. In a limited neonatal screening for free thyroxine $\left(\mathrm{fT}_{4}\right)$ in 80000 newborn infants, $\mathrm{RTH}$ was detected in 1 of 40000 live births (1).

Elevated serum $\mathrm{TH}$ levels in the setting of nonsuppressed thyrotrophin (TSH) levels reflect the reduced response of target tissues. Two different forms of RTH have been described, the generalized and pituitary forms. Generalized RTH is the most prevalent form, in which 
patients are clinically euthyroid. Some subjects can exhibit signs of hyperthyroidism in one tissue and findings suggestive of hypothyroidism in other tissues according to the distribution of the different thyroid receptor subtypes. Goitre is reported to be the most common feature followed by sinus tachycardia. Other features are growth delay or attention deficit. Signs and symptoms vary in patients with the same mutation, even in the same family (2).

It is well known that high TSH levels, as described in RTH syndrome, are associated with an increased risk of developing thyroid nodules, with subsequent growth and malignancy (3), and with advanced stages of thyroid cancer (4). TSH has been reported to act as a growth factor in thyroid tissue. Despite the exact role of RTH in thyroid carcinogenesis being still undefined, three recent reports (5) (6) (7) have documented two cases of RTH associated with papillary thyroid carcinoma (PTC). To the best of our knowledge, we report the first case of multiple Hürthle cell adenomas associated with RTH.

\section{Case presentation}

In July 2006, a 29-year-old Caucasian man without a family history of thyroid disease presented with a palpable and painless mass in the neck. The patient had a history of mild mitral valve insufficiency diagnosed at the age of 15 years and hypertension since 28 years, treated with atenolol $50 \mathrm{mg}$ a day. Physical examination revealed blood pressure of $135 / 74 \mathrm{mmHg}$ and heart rate of 80 b.p.m. His BMI was $23.6 \mathrm{~kg} / \mathrm{m}^{2}$. Cervical examination revealed two palpable hard nodules with a mildly enlarged thyroid gland. No other abnormalities were found.

\section{Investigation}

Increased $\mathrm{fT}_{4}$ and free triiodothyronine ( $\mathrm{fT}_{3}$ ) levels were found in the context of unsuppressed TSH levels (Table 1). The determination of $\mathrm{fT}_{4}$ and $\mathrm{fT}_{3}$ levels was performed by electrochemiluminescent immunoassay using the equipment provided by Roche (Elecsys E170). Tests carried out for anti-thyroid receptor, anti-thyroglobulin and anti-thyroid peroxidase antibodies were negative. No alterations in lipid profile were found. Sex hormonebinding globulin and albumin levels were within the normal range.

All first-degree relatives of the patient were studied. Tests carried out for thyroid antibodies were negative in all the cases. None of the relatives studied exhibited any alteration in thyroid function.

Familial dysalbuminaemic hyperthyroxinaema was unlikely due to an increase in not only total $\mathrm{T}_{4}$ levels, but also $\mathrm{fT}_{3}$ and $\mathrm{fT}_{4}$ levels, and especially due to the high levothyroxine ( $\left.\mathrm{L}-\mathrm{T}_{4}\right)$ doses required to maintain TSH levels within the normal range. TSH-secreting pituitary adenoma was ruled out, because the patient had no clinical features of thyrotoxicosis, a negative magnetic resonance imaging scan of the pituitary gland, and a normal level of the $\alpha$-subunit of TSH $(<0.25 \mathrm{mUI} / \mathrm{ml}, n$ : $0-0.8)$.

Thyroid ultrasonography revealed an enlarged thyroid gland with multiple well-defined nodules in the left lobe. The two biggest nodules measured $17 \times 27$ and $21 \times 24 \mathrm{~mm}$ respectively. Fine-needle aspiration cytology (FNAC) of both the nodules revealed few follicular cells with microcalcifications. A left hemithyroidectomy was scheduled, and the pathological examination disclosed four Hürthle adenomas.

Two years later, thyroid ultrasonography revealed four new nodules in the right lobe. FNAC of the biggest one revealed follicular cells with oncocytic metaplasia. Removal of the remaining thyroid lobe disclosed Hürthle adenoma $(8 \mathrm{~mm})$ and three hyperplasic nodules.

Genomic DNA was isolated from the peripheral blood leukocytes of the patient. PCR amplification was conducted from axon 7 to axon 10 of the $T R \beta$ gene. The sequences were analysed using the Sequence Pilot Software (JSI Medical Systems, Kippenheim, Germany). Screening of all the known mutations in the $T R \beta$ gene was negative.

Table 1 Changing levels of thyroid hormones and TSH pre and post surgery and before and after replacement therapy with levothyroxine.

\begin{tabular}{|c|c|c|}
\hline & Baseline & $\begin{array}{c}\text { After } \\
\text { hemithyroidectomy } \\
\text { (without } \mathrm{L}^{-\mathrm{T}_{4}} \text { treatment) }\end{array}$ \\
\hline TSH (0.27-4.2 mIU/l) & 2.12 & 5.44 \\
\hline $\mathrm{FT}_{4}(0.7-1.8 \mathrm{pmol} / \mathrm{l})$ & 3.06 & 3.08 \\
\hline $\mathrm{FT}_{3}(1.8-4.6 \mathrm{ng} / \mathrm{dl})$ & 8.35 & 7.42 \\
\hline
\end{tabular}

\begin{tabular}{c} 
After \\
$\begin{array}{c}\text { hemithyroidectomy } \\
\left.\text { (with } \mathrm{L}_{4} \mathrm{~T}_{4} 150\right)\end{array}$ \\
\hline 3.88 \\
3.68 \\
\end{tabular}

\begin{tabular}{c}
$\begin{array}{c}\text { After total } \\
\text { thyroidectomy } \\
\left(\mathrm{L}-\mathrm{T}_{4} 300\right)\end{array}$ \\
\hline 30 \\
3.39 \\
\end{tabular}

\begin{tabular}{|c|}
\hline $\begin{array}{c}\text { After } \\
\text { thyroidectomy } \\
\left(\mathrm{L}-\mathrm{T}_{4} 450\right)\end{array}$ \\
\hline 2.2 \\
\hline 4.7 \\
\hline 5.55 \\
\hline
\end{tabular}

$\mathrm{FT}_{4}$, free thyroxine; $\mathrm{FT}_{3}$, free triiodothyronine; $\mathrm{TSH}$, thyrotrophin. 


\section{Treatment}

After surgery, the patient needed a dose of $450 \mu \mathrm{g} / \mathrm{day}$ $(6.1 \mu \mathrm{g} / \mathrm{kg}$ per day) to maintain TSH levels comparable to the preoperative values and to be clinically euthyroid. Malabsorption was ruled out. His heart rate was 70-80/min.

\section{Outcome and follow-up}

The patient is currently well.

\section{Discussion}

Excluding other aetiologies, the patient was diagnosed with RTH. No other family member exhibited any thyroid dysfunction. De novo RTH- $\beta$ mutations have been reported to be responsible for $27 \%$ of RTH cases (7). Genetic mutation has not been found in the current case. The genetic study includes the complete sequence of exons 7, 8, 9 and 10. Earlier, it has been reported that $15 \%$ of RTH cases have no TR $\beta$ mutations (7). The phenotype of these patients does not differ from that of cases with $T R \beta$ gene mutations, suggesting the involvement of other as-yet unidentified genes encoding the messengers along the intracellular pathways downstream to the receptor.

Of note, RTH in this patient was concomitant with the development of five Hürthle cell adenomas, a rare thyroid neoplasm of follicular cell origin, and hyperplasic nodules. Surgery is only rarely required in RTH. Total thyroidectomy was the best option as cytology was suggestive of malignancy.

Hürthle cell adenomas, also known as oncocytomas or oxyphilic thyroid adenomas, represent a rare subgroup of follicular thyroid lesions, surrounded by a thin capsule and characterized by cells with distinctive eosinophilic cytoplasm.

Three recent reports have documented three cases of RTH associated with PTC (5) (6) (7). The first case is a 38-year-old Korean woman with generalized RTH and incidental PTC (5). She presented with goitre and no signs or symptoms of hyperthyroidism. A missense mutation in exon 9 of the TR $\beta$ gene that causes the substitution of threonine with methionine at codon 310 was found. No family members were affected. FNAC revealed suspicious features of malignancy. After thyroidectomy, pathological examination revealed two micro-PTCs in both the lobes. She had no signs of hypothyroidism under treatment with $250 \mu \mathrm{g} /$ day of $\mathrm{L}-\mathrm{T}_{4}(5.1 \mu \mathrm{g} / \mathrm{kg}$ per day). The second case is a 29-year-old Brazilian man with a family history of RTH (6).
He was diagnosed with RTH at the age of 15 years and his medical history included atrial fibrillation. Analysis of the $T R \beta$ gene revealed a missense mutation in exon 9 causing a change of the amino acid alanine to threonine at codon 317. Thyroidectomy was indicated after two unsatisfactory FNAC procedures. Intraoperative frozen-section analysis revealed PTC, and bilateral cervical lymph node dissection was performed. Pathological examination indicated multicentric papillary carcinoma without lymph metastasis. Signs of hypothyroidism improved under treatment with $400 \mu \mathrm{g} /$ day of $\mathrm{L}^{-} \mathrm{T}_{4}(5.8 \mu \mathrm{g} / \mathrm{kg}$ per day). The third reported case is a 29-year-old woman with generalized RTH and incidental PTC (7). She presented with diffuse goitre and 5 -year symptoms of palpitation and nervousness. Failure to respond to anti-thyroid drugs led to subtotal thyroidectomy. Pathological examination revealed an 8-mm PTC and total thyroidectomy was indicated. Screening of family members revealed two siblings with elevated serum $\mathrm{fT}_{3}$ and $\mathrm{fT}_{4}$ levels with normal serum TSH concentrations but no thyrotoxic manifestations. Sequencing of the TR $\beta$ gene revealed a single-nucleotide substitution resulting in the replacement of the normal methionine with a threonine at codon 334. She was clinically asymptomatic under treatment with $300 \mu \mathrm{g} /$ day of $\mathrm{L}-\mathrm{T}_{4}$.

It is important to consider mutations in the TSH receptor (TSHR) during differential diagnosis. A 33-yearold man presented with multinodular goitre (7). Thyroid ultrasound demonstrated a hypoechoic nodule measuring $8 \times 10 \times 8 \mathrm{~mm}$ with FNAC being compatible with PTC. Histopathological examination after total thyroidectomy with central lymph node dissection revealed a PTC focus of $12 \mathrm{~mm}$ in the longest diameter with capsular invasion. A novel nucleotide substitution resulting in the replacement of the normal isoleucine with phenylalanine (I364F) in the extracellular domain of the TSHR was described. TSHR mutation was incidental and did not correlate with the increased serum TSH levels or any of the thyroid test abnormalities in the subject. The required dosage of $\mathrm{T}_{4}$ was $250 \mu \mathrm{g} /$ day. Seven family members were studied. Four exhibited the same nucleotide substitution with different phenotypes.

The exact role of RTH in carcinogenesis is still unknown. According to previous studies, TSH acts as a growth factor due to the high levels and an increased bioactivity of TSH as described in RTH (8). In the reported case, with respect to the normal values of TSH, it is possible that TSH acts as a growth factor through its increased bioactivity. In animal models, spontaneous development of thyroid follicular carcinoma has been described in mice homozygous for a target mutation in the $\operatorname{Tr} \beta$ gene (9). 
The metastatic thyroid cancer exhibited both anaplastic and follicular patterns (10). Molecular analyses in these mice revealed the activation of the cyclin 1-cyclindependent kinase-4-transcription factor E2F1 pathway, known to be associated with thyroid tumour cell proliferation (9). In addition, mutation of a single allele of the TR $\beta$ gene is also sufficient for follicular thyroid carcinoma to develop in mice treated with propylthiouracil, in which TSH levels increase even more (9). Recently, Franco et al. (11) have found that the TSH signalling pathway may predispose thyroid cells to BRAF-induced transformation in mice with a thyroid-specific knocking of oncogenic Braf (LSL-Braf ${ }^{\mathrm{V} 600 \mathrm{E}} / \mathrm{TPO}-\mathrm{Cre}$ ). However, thyroid cancer is still an uncommon occurrence in patients with genetically confirmed RTH, and it must be investigated.

There are some study limitations of the reported case. TRH test was not performed in this patient. None of the investigations reported have $100 \%$ sensitivity or specificity to exclude TSHoma either alone or in combination. Despite this limitation, patient outcomes support the diagnosis of RHT. Familial dysalbuminaemic hyperthyroxinaema was unlikely, given an increase not only in total $\mathrm{T}_{4}$ levels, but also in $\mathrm{fT}_{4}$ and $\mathrm{fT}_{3}$ levels, in the same proportion.

\section{Declaration of interest}

The authors declare that there is no conflict of interest that could be perceived as prejudicing the impartiality of the research reported.

\section{Funding}

This research did not receive any specific grant from any funding agency in the public, commercial or not-for-profit sector.

\section{Patient consent}

The authors confirm that written informed consent was obtained from the patient.

\section{Author contribution statement}

$S$ Mauri is the named physician of the patient. G Xifra, S Mauri, J M Fernández-Real and W Ricart are co-authors of the article.

\section{References}

1 LaFranchi SH, Snyder DB, Sesser DE, Skeels MR, Singh N, Brent GA \& Nelson JC 2003 Follow-up of newborns with elevated screening $T_{4}$ concentrations. Journal of Pediatrics 143 296-301. (doi:10.1067/ S0022-3476(03)00184-7)

2 Brucker-Davis F, Skarulis MC, Grace MB, Benichou J, Hauser P, Wiggs E \& Weintraub BD 1995 Genetic and clinical features of 42 kindreds with resistance to thyroid hormone. The National Institutes of Health Prospective Study. Annals of Internal Medicine 123 572-583. (doi:10.7326/0003-4819-123-8-199510150-00002)

3 Boelaert K, Horacek J, Holder RL, Watkinson JC, Sheppard MC \& Franklyn JA 2006 Serum thyrotropin concentration as a novel predictor of malignancy in thyroid nodules investigated by fine-needle aspiration. Journal of Clinical Endocrinology and Metabolism 91 4295-4301. (doi:10.1210/jc.2006-0527)

4 McLeod DS, Cooper DS, Ladenson PW, Ain KB, Brierley J, Fein HG, Haugen BR, Jonklaas J, Magner J, Ross DD et al 2013 Prognosis of differentiated thyroid cancer in relation to serum TSH and thyroglobulin antibody status at time of diagnosis. Thyroid. In press. (doi:10.1089/thy.2013.0062)

5 Kim HK, Kim D, Yoo EH, Lee JI, Jang HW, Tan AH, Hur KY, Kim JH, Kim KW, Chung JH et al 2010 A case of resistance to thyroid hormone with thyroid cancer. Journal of Korean Medical Science 25 1368-1371. (doi:10.3346/jkms.2010.25.9.1368)

6 Weinert LS, Ceolin L, Romitti M, Camargo EG \& Maia AL 2012 Is there a role for inherited TR $\beta$ mutation in human carcinogenesis? Arquivos Brasileiros de Endocrinologia e Metabologia 56 67-71. (doi:10.1590/S000427302012000100010)

7 Ünlütürk U, Sriphrapradang C, Erdoğan MF, Emral R, Güldiken S, Refetoff S \& Gülü S 2013 Management of differentiated thyroid cancer in the presence of resistance to thyroid hormone and TSH-secreting adenomas: a report of four cases and review of the literature. Journal of Clinical Endocrinology and Metabolism 98 2210-2217. (doi:10.1210/ jc.2012-4142)

8 Persani L, Tonacchera M, Beck-Peccoz P, Vitti P, Mammoli C, Chiovato L, Elisei R, Faglia G, Ludgate M, Vassart G et al 1993 Measurement of cAMP accumulation in Chinese hamster ovary cells transfected with the recombinant human TSH receptor (COH-R): a new bioassay for human thyrotropin. Journal of Endocrinological Investigation 16 511-519.

9 Zhao L, Zhu X, Won Park J, Fozzatti L, Willingham M \& Cheng SY 2012 Role of TSH in the spontaneous development of asymmetrical thyroid carcinoma in mice with a targeted mutation in a single allele of the thyroid hormone- $\beta$ receptor. Endocrinology 153 5090-5100. (doi:10.1210/en.2012-1600)

10 Suzuki H, Willingham MC \& Cheng SY 2012 Mice with a mutation in the thyroid hormone receptor $\beta$ gene spontaneously develop thyroid carcinoma: a mouse model of thyroid carcinogenesis. Thyroid $\mathbf{1 2}$ 963-969. (doi:10.1089/105072502320908295)

11 Franco AT, Malaguarnera R, Refetoff S, Liao XH, Lundsmith E, Kimura S, Pritchard C, Marais R, Davies TF, Weinstein LS et al 2011 Thyrotrophin receptor signaling dependence of Braf-induced thyroid tumor initiation in mice. PNAS 108 1615-1620. (doi:10.1073/pnas.1015557108) 